\title{
PIERUCCINI, Maria Cristina. Os Rocha Loures: uma família paranaense em 300 anos de história. Curitiba: Posigraf, 1995. 204p.
}

\author{
Ana Crhistina Vanali ${ }^{1}$
}

- Enviado em 27/02/2016

- Aprovado em 03/05/2016

A família Rocha Loures ${ }^{2}$ está presente no poder político e econômico do Paraná desde a época da fundação da cidade de Curitiba, há mais de trezentos anos. A história da família se confunde com a história paranaense. O livro é um estudo genealógico sobre os mais de 300 anos de história da tradicional e histórica família Rocha Loures reconstituída através da trajetória de um membro da família: João Alves da Rocha Loures (1900-1986).

A obra está dividida em quatro partes. Na primeira, "Dos campos de Curitiba aos campos gerais", a autora faz a reconstituição de como essa família, originária dos clãs patriarcais fundadores de Curitiba (Mateus Leme e Carrasco do Reis) se movimenta sentido Campos Gerais. A figura central abordada nessa parte é Antonio Rocha Loures, que participou da Real Expedição da Conquista de Guarapuava, em 1820, ao lado de Diogo Pinto e do Padre Chagas (do qual era parente). A autora remonta à época da colonização e povoamento do território paranaense que começou por Paranaguá. Com a descoberta do ouro de aluvião no planalto curitibano, no século XVIII (apesar de desde 1560 ter-se notícia de ouro de lavagens nesse território) inicia-se o povoamento de Curitiba com Mateus Leme (primo de Gabriel de Lara, fundador de Paranaguá) que aos vinte e nove dias do mês de março de 1693 faz a instalação da Vila de Nossa Senhora da Luz e

\footnotetext{
${ }^{1}$ Doutoranda em Sociologia pela Universidade Federal do Paraná. Endereço eletrônico: anacvanali@yahoo.com.br
}

2 “A origem do sobrenome Rocha Loures data do início do século XVIII quando veio para o Brasil, procedente da cidade portuguesa de Loures, o capitão Antonio João da Costa que se casou com Maria da Rocha de Jesus. Desta união nascera um varão, em cujo nome o pai agregaria em homenagem à terra distante, ficando seu nome João da Rocha Loures". (PIERUCCINI, 1995, p.3) 
Bom Jesus dos Pinhais. Sete antepassados da família Rocha Loures assinaram essa ata, a saber: Balthazar Carrasco dos Reis, Matheus Martins Leme, Manoel Picam de Carvalho, Garcia Rodrigues Velho, Luis de Goes, Antonio Rodrigues Seixas e Manoel Soares, a maioria com sesmarias nos campos de Curitiba e região. Portanto, a família Rocha Loures descende do núcleo povoador seiscentista de Curitiba que era aparentado entre si, originários das antigas famílias paulistas constituídas por elementos vindos de Portugal. Os clãs líderes eram Carrasco dos Reis e Martins Leme, que constituíam a elite e cujos descendentes seriam figuras públicas de destaque na sociedade paranaense. Os integrantes desses clãs e seus descendentes tornaram-se grandes tropeiros e criadores de gado no Paraná e contribuíram para a ocupação dos Campos Gerais expandido sua área de atuação além do planalto curitibano.

Na segunda parte, "Dos campos gerais às missões", vemos que vários descendentes dos patriarcas fundadores de Curitiba foram convidados para participarem da Real Expedição da Conquista de Guarapuava, no início do século XIX, comandada por Diogo Pinto de Azevedo Portugal. Nessa parte a autora destaca a atuação de Antonio da Rocha Loures, que fazia parte da Cavalaria de Curitiba, nessa expedição ao lado de Diogo Pinto e Padre Francisco das Chagas Lima (que era seu parente por parte do tronco Carrasco dos Reis). Essa expedição é composta de dois momentos: a expedição propriamente dita e a ocupação e organização da conquista e ambos marcados pelas divergências entre Diogo Pinto e o Padre Chagas. A autora ressalta que nesses momentos de atritos os laços de parentesco falaram mais alto e Antonio Rocha Loures sempre se manteve fiel ao Padre Chagas. Diversas vezes Antonio substituiu Diogo Pinto no comando da expedição pois este ausentava-se devido as convocações da Junta ou por motivo de doença. Assim, a conquista ficou mais nas suas mãos e na do Padre Chagas, prova disso é que ambos são signatários do auto da fundação da Freguesia de Nossa Senhora do Belém, atual Guarapuava. Com o falecimento de Diogo Pinto em 1820 é encerrada a Real Expedição. Antonio Rocha Loures permaneceu no quartelamento de Atalaia comandando o destacamento militar e tratando da localização das sesmarias. Mais tarde é chamado para atuar na abertura de um caminho para as Missões, mas sentindo-se "velho" passa a missão aos filhos Francisco e João Cipriano que seguem o exemplo do pai no trabalho de colonização. Os irmãos comandam a expedição de Guarapuava a Missões/Rio Uruguai. João Cipriano permanece no Rio Grande do Sul, originando o tronco gaúcho da família e Francisco retorna para Guarapuava.

Na terceira parte, "De fazendeiros a bacharéis", é destacado como os membros da família Rocha Loures tornam-se grandes proprietários de terras na região campeira, pois com a abertura dos 
caminhos de Guarapuava, Palmas e Missões o tropeirismo e o fornecimento de campos de invernagem para as tropas era um negócio altamente lucrativo. Assim, ao lado do poder econômico que conquistaram, começam a aliar o poder político fornecendo diversas lideranças políticas regionais. A autor cita o exemplo de João Ferreira dos Santos, maragato, que foi morto durante a Revolução Federalista e era o sogro de Jesuíno Alves da Rocha Loures, que assume as responsabilidades da família após a sua morte. Jesuíno é o pai de João Alves, figura central que a autora utiliza para a reconstituição genealógica da família Rocha Loures. Jesuíno tenta diversificar os negócios da família, mas não foi bem-sucedido e acabou empobrecendo. Para recuperar a condição econômica da família ele percebe a necessidade de transformação do estilo de vida que o início do século XX impunha. Então, a exemplo de seus sobrinhos Affonso e Marins Alves de Camargo que haviam saído de Guarapuava para estudar Direito em São Paulo rompendo com a tradição de fazendeiros da família e indo atrás de títulos de bacharéis, Jesuíno decide fazer o mesmo com os filhos Silvano, João e Josino, que se formam em Agronomia, Direito e Medicina, respectivamente. A autora destaca como no período da Primeira República (1889-1930), apesar da família Rocha Loures estar em recuperação financeira, ela já integrava a oligarquia dominante do Estado do Paraná via relações de parentesco e acaba fornecendo indícios, sem aprofundar, de que podia-se perceber a prática do nepotismo através da boa colocação profissional, em altos cargos de relevo na administração pública, dos membros da família Rocha Loures. Alguns nomes da família Rocha Loures são destacados nessa parte por terem ingressado na vida política, como Renato Loures Bueno que foi vereador em Londrina, deputado estadual em quatro legislaturas, deputado estadual em uma legislatura e candidato a prefeitura de Londrina. Sylvano Alves da Rocha Loures que foi eleito deputado estadual, mas não chegou a exercer o mandato pois foi deposto pela Revolução de 30. Annibal Alves da Rocha Loures que foi prefeito da Colônia Mineira (1928), mas não chega a finalizar o mandato por "falta de vocação política, pois candidatou-se porque os primos Affonso e Marins Camargo insistiram" (p.98). Josino Alves da Rocha Loures que foi vereador em Joinville, vereador em Londrina, deputado federal e secretário de trabalho a assistência social no segundo governo Lupion.

Na quarta parte, “João Alves da Rocha Loures: estudo genealógico”, está a parte mais densa da obra. A autora apresenta a trajetória de João Alves da Rocha Loures passando pela sua infância, formação, vida profissional, vida acadêmica, militância política e atividade empresarial. João Alves era tataraneto de Antonio da Rocha Loures. Após, temos a árvore genealógica da família Rocha Loures, tendo ao centro João Alves. A autora recua quinze gerações sucessivas do tronco paterno e dez do tronco materno fornecendo um riquíssimo trabalho de pesquisa que proporciona um banco 
de dados valiosíssimo para estudos futuros. Para a reconstituição genealógica a autora utilizou documentos de instituições públicas, documentos pessoais dos familiares, bibliografia, correspondências pessoais e profissionais, além da tradição oral da família com entrevistas e depoimentos. 